\title{
Girdi-Çıktı Analizi Yaklaşımıyla Türkiye ve Kazakistan Ekonomilerinin Karşılaştırılması
}

\author{
Comparing the Economies of Turkey and Kazakhstan by Input-Output Analysis
}

Tuncer ÖZDiL ${ }^{1}$, Ainura TURDALIEVA ${ }^{2}$

\begin{abstract}
ÖZET
Günümüzde bilişim teknolojilerindeki başdöndürücü gelişmeler ve küreselleşmenin de etkisiyle ekonomik anlamda ülkeler arasındaki sınırlar ortadan kalkmış, önceleri daha dar bir coğrafi alanda yaşanan rekabet dünya geneline yayılarak gelişmiş ve gelişmekte olan tüm ülke ve bölgeleri doğrudan etkiler hale gelmiştir. Bu süreçte; benzer özelliklere, coğrafyaya ve çıkarlara sahip ülkeler güçlerini birleştirerek daha güçlü rekabet ortamı yaratma çabasına girişmişlerdir.
\end{abstract}

Kuşkusuz etkin ekonomik işbirliği, dağılma sonrası dönemde hızla ekonomik kalkınmalarını sağlama çabasında olan Orta Asya Türk Cumhuriyetleri için de geçerlidir. Ekonomik işbirliğinin ülkelerin karşılıklı ekonomik çıkarlarını arttıracak şekilde gerçekleştirilebilmesinde, ülke ekonomilerinin üretim yapılarının karşılaştırmalı olarak incelenmesi ve aradaki ilişkilerin buradan elde edilen sonuçlara göre planlanması son derece önemlidir.

Çalışmamızda böyle bir düşünceyle, Türkiye ve Kazakistan ekonomilerinin üretim yapılarının karşılıklı incelenmesi amaçlanmaktadır. Her iki ülke üretim yapılarındaki benzerlik ve farklııkların karşılaştırmalı incelenmesi girdi-çıktı analizi yaklaşımıyla yapılmaktadır.

Çalışmada, her iki ülkede İstatistik Kurumu tarafından hazırlanan birbirine uygun, yakın tarihli Girdi-Çıktı Sonuç tabloları kullanılarak, ileri-geri bağlantı etkileri ve kilit sektörlerin karşılaştırılması, aragirdi kullanımlarında etkenlik ve üretim tekniklerindeki benzerliklerin araştıııması yoluyla dış ticaret ve üretim yapılarının karşılaştırılması yapılacaktır. Elde edilen sonuçlar iki ülkenin ekonomik ilişkilerinin daha da geliştirilebilmesi bakımından değerlendirilerek taraflara öneriler getirilmeye çalışılacaktır.

Anahtar Sözcükler: Girdi-çıktı analizi, üretim yapısı, ekonomik ilişkiler.

\section{GiRiş}

Günümüzde bilişim, iletişim, ulaştırma ve üretim alanında gerçekleşen baş döndürücü teknolojik gelişmeler ulusal ekonomileri doğrudan etkileyerek ekonomik üretim sektörleri arasındaki karşılıklı etkileşimi arttırmış, ülkeler arasındaki sınırlar ortadan

\begin{abstract}
Nowadays, progress in information technologies and globalization influenced disappearing the borders between countries in economic terms; the competition narrowed only in one geographic area previously, has spread worldwide and became influential directly on all countries and territories. In this process, countries that have similar properties, geography and interests, have joined forces to create a stronger competitive environment.
\end{abstract}

Effective economic cooperation also applies to the Central Asian Turkish Republics, which are trying to ensure the rapid economic development in the period after dissolution. The results obtained from comparative study of the production structures is extremely important to countries for achieving economic cooperation to increase mutual economic interests, the relations between their countries' economies and planning.

The purpose of this paper is to describe the production structures of Turkey and Kazakhstan economies. The comparative analysis of the similarities and differences in the production structures of both countries made by input-output approach.

Given research is based on analysis of input-output tables prepared by the Statistics Committees of two countries. For the study purpose forward and backward linkages, key sectors, efficiency in intermediate product usage, production techniques, external trade and production structure were calculated and compared on sectoral and macro-level. The results, obtained from the analysis, allow giving recommendations to further development of economic relations between countries.

Keywords: Input-output analysis, production structure, economic relations.

kalkmış rekabet dünya geneline yayılmıştır. Benzer sosyo kültürel özelliklere, coğrafyaya ve ortak çıkarlara sahip ülkeler güçlerini birleştirerek daha güçlü rekabet ortamı yaratma çabasına girişmişlerdir. Bu süreç ülkeler arasında ekonomik ilişkilerin daha da arttırılmasına yol açmıştır. 
1990 dağılma sonrası dönemde Orta Asya Türk Cumhuriyetleri, tarihten gelen ortak kültürel bağlar nedeniyle ülkemiz için çok daha önemli hale gelmişlerdir. Orta Asya Türk Cumhuriyetleri içerisinde Kazakistan doğal kaynakları, jeopolitik konumu nedeniyle ekonomik yönden zengin bir ülkedir. Bölge ekonomik ve siyasal yönden önemli bir role sahiptir. Ülkemizin Kazakistan'la olan ekonomik ilişkilerinin daha da geliştirilmesi başta her iki ülke olmak üzere tüm bölge ülkeleri için önemli kazanç ve fırsatların ortaya çıkmasına yol açacaktır.

Bu çalışmanın temel amacı; Türkiye ve Kazakistan ekonomilerinin üretim yapılarının karşılaştırmalı olarak incelenerek elde edilen sonuçlara göre taraflara aradaki ekonomik işbirliğini daha da arttıracak önerilerde bulunmaktır. Her iki ülke ekonomik yapılarının karşılaştırılması betimleyici istatistikler yardımıyla da yapılabilir. Ancak oldukça geniş kapsamlı ekonomik yapı kavramına bağlı olarak; aradaki karşılıklı etkileşimi ve ekonomik yapının farklı yönlerini yansıtabilmesi incelemenin girdi çıktı analizi yaklaşımıyla yapılmasının temel nedenini oluşturmaktadır. Bu amaçla, araştırmada her iki ülke İstatistik Kurumu tarafından en son hazırlanan, Türkiye için 2002 yılı, Kazakistan için ise 2009 yılı Girdi-Çıktı tabloları kullanılmıştır. Ekonomik üretim yapılarının karşılaştırılması, her iki ülke için toplam ileri ve geri bağlantı etkilerinin incelenmesi, endüstriyel bağınlaşmanın, üretim tekniklerindeki değişmenin, aramalı kullanımındaki etkenliğin araştırılmasıyla gerçekleştirilmiştir.

\section{TÜRKIYE VE KAZAKISTAN EKONOMILERI}

Kazakistan, eski Sovyetler Birliğinin dağılmasıyla 1990'lı yılların başında bağımsızlığını elde etmiş zengin petrol yatakları ve doğal gaza sahip 2008 yılı itibariyle 15,8 milyon nüfus ve 2.724 .900 km² yüzölçümüne sahip bir Orta Asya ülkesidir. Reel GSMH artışı 2007 yılı itibariyle \% 8,9, 2008 yılı için \% 3,2, 2009 yılı \% 1,2 olarak gerçekleşmiştir. 2008 yılı, Kişi Başına Düşen Milli Gelir 2000 yılı sabit fiyatlarıyla 2371 \$ olup satınalma gücü paritesine göre 11.264 \$'dır. 2008 yılı için işsizlik oranı \%8,8, 2009 yılı \%6,6,dır. 2009 yılı için milli gelirin \% 53,3'ünü hizmet, \% 40,3'ünü sanayi, \% 6,4'ünü tarım sektörleri oluşturmaktadır. 2008 yılı tüketici fiyatları enflasyonu ortalama olarak \% 9,5, 2009 yılı için \% 7,3 olmuştur (The Economist Intelligence Unit, 2010). Ülkenin ihracatı 72,0 milyar dolar iken ithalatı 38,5 milyar dolar olarak gerçekleşmiştir. Başlıca Sanayi Malları; Petrol, kömür, manganez, kromit, kurşun, çinko, bakır, titanyum, boksit, altın, gümüş, sülfür, demir ve çelik, traktörler ve diğer tarımsal makineler, elektrikli makineler, inşaat malzemeleridir. Başlıca Tarım Ürünleri Hububat (başta buğday), pamuk, hayvancılık ürünleridir.

Türkiye'nin 2008 yılı itibariyle kişi başına milli geliri 2000 yılı sabit fiyatlarıyla 5.288 \$ olup satın alma gücü paritesine göre, 14.995 \$'dır. 2009 yılı için aynı değerler 4969 \$ ve 14.228 \$ olarak gerçekleşmiştir. 2008 yılı işsizlik oranı \% 11, 2009 yılı \%14 olmuştur. 2008, 2009 yılları için tüketici fiyat endeksine göre enflasyon oranları sırasıyla \% 10,5 ve \% 6,5 olarak gerçekleşmiştir. 2009 yılı için milli gelir içinde hizmetler sektörünün payı \% 72,6, Sanayi payı \% 19,1, tarım payı \% 8,3 olmuştr. İhracat 132 milyar dolar, ithalat 202 milyar dolardır. 2008 yılı için, Türkiye'nin ihraç ürünlerinin \% 93,2'ni imalat sanayi, \% 4,7'ni tarım ve madencilik sektörü ürünleri oluşturmaktadır. İthal ürünleri içerisinde GSYIH'ya oran olarak yaklaşık \% 25 civarı oranla en çok tüketim malı ithalatı yapılmakta bunu \%20'lik payla aramalı ithalatı ve \% 4-5 civarı payla sermaye malları ithalatı izlemektedir. Toplam ithalatta sektörel paylar ise, \% 75,8 oranında imalat, $\%$ 18,2'lik payla madencilik ve \% 3,4'lük payla tarım ürünleri olarak gerçekleşmiştir (http://www.tuik. gov.tr/UstMenu.do?metod=temelist, erişim tarihi 17.05.2012).

Kazakistan sahip olduğu üretim yapısı itibarı ile daha ziyade ham madde ve yarı mamul ihracatçısı bir ülkedir. Petrol ve petrol ürünleri, demirli metaller, kimyasallar, makineler, hububat, yün, et, kömür ülkenin başlıca ihraç ürünleridir. İhracatın yarısından fazlasını petrol ve petrol ürünleri oluşturmaktadır. Tüketim malları ihracatı çok sınırlı düzeydedir. Ülkenin başlıca ihraç ürünleri olan petrol, gaz ve metallerin ihracatın önemli bir kısmını oluşturması, Kazakistan'ın dış ticaret dengesini uluslararası mal fiyatlarındaki değişmelere karşı korunmasız hale getirmektedir. Kazakistan bölgedeki en önemli hububat ihracatçılarından biridir. Buğday, ülkenin ihracatı açısından büyük önem taşımaktadır. Ülkenin ithalatında ise yatırım ve tüketim malları önemli yer tutmaktadır. Makine ve ekipman, metal ürünler ve gıda maddeleri ülkenin ithalatında önem arz eden ürün gruplarıdır (Somuncuoğlu, 2011:18).

Günümüzde Kazakistan dış ticaretinin yönü eski Sovyetler Birliği ülkeleri dışındaki ülkelere yönelmiştir. Bunda Kazakistan'ın dünyanın önde gelen ülkelerine gerçekleştirdiği petrol ihracatından elde ettiği yüksek gelir önemli rol oynamaktadır. İtalya Kazakistan'ın ihracatında \% 17 oranındaki payı ile birinci sıradadır. İtalya'yı \% 16 ile İsviçre ve \% 11 ile Çin takip etmektedir. Rusya, Kazakistan'ın ithalatından en fazla pay alan ülkedir. Bunda iki ülke arasındaki ticareti kolaylaştırıcı uygulamalar ve anlaşmalar rol oynamaktadır. İki ülke 
arasındaki geçmişten gelen ticari ve siyasi bağlar günümüzde de korunmaktadır. Rusya, Kazakistan'a petrol ve petrol ürünleri, gıda sanayi ürünleri ve gıda ham maddeleri, makine ve ekipman, motorlu taşıt araçları tedarik eden başlıca ithalatçı olma özelliğini korumaktadır. Rusya'nın ülkenin ithalatındaki payı \% 36,4'tür. Rusya'yı \% 12,1 ile Çin, \% 6,8 ile Almanya takip etmektedir. Türkiye Kazakistan'ın dış ticaretinde ilk 10 ülke arasında 8.sıradadır. Ancak Kazakistan Türkiye'nin en çok ithalat yaptığı 50 ülke içerisinde 34. sırada yer almaktadır. Bu durumda iki ülke arasındaki ekonomik ilişkilerin daha da geliştirilme zorunluluğu ortaya çıkmaktadır.

\section{GIRDI-ÇIKTI ANALIZI YAKLAŞIMIYLA ÜRETIM YAPILARININ INCELENMESI}

Endüstrilerarası mal ve hizmet akımı çok yönlü ve karmaşık bir yapıya sahiptir. Ulusal ekonominin planlanabilmesi için, her şeyden önce, ekonominin yapısını tanımak ve endüstriler arasındaki ilişkileri bilmek gerekir. Girdi-Çıktı Analizi, matematiksel ve istatistiksel teknikler yardımıyla, endüstrilerarası ilişkileri tutarlı olarak inceleyen bir modeldir. Bir ekonomik sistemin belirli yapısal özelliklerini tanımlayan bir veriler toplamı ve sistemin belirli bir zaman aralığı içinde belirli bir anındaki davranışını etkileyici ve açıklayıcı analitik bir teknik olarak tanımlanabilir (Todaro, 1987:17). Analizin temeli, herhangi bir ülke ekonomisinin kendi içerisinde homojen ya da birbirine benzer mallar üreten endüstrilere bölünebilmesi ve bu endüstrilerin birbirleriyle ve ekonomiyle olan etkileşimlerinin matematiksel ifadesine dayanır. Girdi-Çıktı modelleri sektörel tutarlılık planlamasından dış ticaret teorilerinin sınanmasına, beşeri kaynak planlamasından bölgesel planlamaya yapısal değişim çözümlemelerinden endüstrilerarası bağınlaşma çözümlemelerine kadar çok çeşitli alanlarda yaygın olarak kullanılmaktadırlar. Ekonominin üretim, tüketim, dış ticaret v.b. gibi çeşitli birimleri arasındaki karşılıklı ilişkileri birarada ekonomi genelinde ve sektörel düzeyde inceleme olanağını oldukça basit ve uygulanabilirliği yüksek tekniklerle vermesi girdi-çıktı modellerinin uygulamadaki en önemli üstünlüğüdür.

Ekonomik yapının önemli bir unsurunu üretimde sektörler arasında ortaya çıkan karşııklı bağımlılıklar oluşturur. Üretim sürecinde ekonomide hiç bir sektör birbirinden bağımsız, yalıtılmış durumda değildir. Ekonomik sektörler arasında mal ve hizmet alışverişlerinden kaynaklanan karşılıklı bağımlııklar vardır. Bu karşılıklı mal ve hizmet alışverişi kısaca endüstriyel bağınlaşma olarak adlandırılmaktadır (Aydoğuş, 2010:125). Endüstriyel bağınlaşma iki şekilde ortaya çıkmaktadır. İlk olarak sektör kendi üretimini gerçekleştirmek için diğer sektörlerden kendi üretiminde kullanmak üzere aragirdi talep eder. Bu geriye bağlantı etkisi olarak bilinir. İkinci olarak sektör kendi çıktısını diğer üretim sektörlerine aragirdi olarak arzeder. Bu ise ileri bağlantı etkisi olarak tanımlanmaktadır. Bu kapsamda endüstrilerarası bağınlaşma çözümlemeleri, sektörel ileri ve geri bağlantı etkilerine göre yapılarak bir yandan ekonomide kilit sektör ve yatırım önceliklerinin belirlenmesinde yaygın olarak kullanılırken, diğer yandan da, endüstrilerarası üretim yapısının hem dönemlerarası hem de ülkelerarası karşılaş̧ııılmasında vazgeçilmez bir teknik olarak ortaya çıkmaktadır.

Girdi-Çıktı modelleri kapsamında üretim yapılarının karşılaştıııması genellikle endüstrilerarası bağınlaşma, üretim teknikleri, aragirdi kullanımları ve temel girdi kullanımları gibi konuları kapsar. (Aydoğuş, 2010:137). Özellikle ülkelerarası yapılan karşılaştırmalarda ülkelerin doğal, coğrafik, gelişmişlik düzeyi, sosyo-kültürel özelliklerinin farklı olması üretim yapılarını da farklılaştıracaktır. Ancak bu farklılıkların nedenlerinden birisi de tabloların hazırlandıkları dönemden ve hazırlanış ilkelerinden kaynaklanan farklılıklardır. Kuşkusuz Girdi-Çıktı analizinin teorik varsayımlarından kaynaklanan sektör sayısı ve içerikleri, toplulaştırma, ekonomi genelindeki enflasyonist etkiler gibi benzer farklılıkların etkilerinin dönemlerarası karşılaştırmalarda hiç ya da çok az olacağı düşünülmektedir.

\subsection{Endüstriyel Bağınlaşma}

Üretim yapısının önemli bir unsuru olarak endüstriyel bağınlaşma yapılarının karşılaştırılması sektörel bağlantı etkilerinin karşılaştııılmasına dayanır. Bu karşılaştırma doğrudan ve toplam ileri ve geri bağlantı etkilerine göre yapılabileceği gibi, sıkça kullanılan bir gösterge Santhanam ve Patil tarafından geliştirilen bağımlıık oranı katsayısıyla da yapılabilir. Herhangi bir "j" sektörünün bağımlılık oranı $b_{j^{\prime}}$

$$
b_{j}=\frac{\left[\frac{1}{2}\left(\sum_{i} x_{j}+\sum_{j} x_{j}\right)\right] / \sum_{j} x_{j}}{x_{j} / \sum_{j} x_{j}}
$$

şeklinde tanımlanabilir. (1) no'lu denklemin paydasındaki terim, $\mathrm{j}$ sektörünün çıktısının ekonominin toplam çıktısına oranını, payındaki terim ise sektörün kullandığı toplam ara girdi ile sektörün ürettiği çıktıya olan toplam ara talebin ortalamasının sektörün çıktısına olan toplam aratalebe oranını göstermektedir (Aydoğuş, 2010:138). Bu katsayı ne kadar büyükse ekonomi bu sektöre o kadar bağımlı deme- 
ktir. Dönemsel karşılaştırmalarda sektörel bağımlılık katsayılarındaki artış ve azalışlara göre dönem içinde bağımlılığın değişimi incelenebilir.

\subsection{Sektörel Üretim Tekniklerinin Karşılaştırılması}

Girdi-çıktı çözümlemesinde dar anlamda sektörel üretim tekniklerini, teknoloji (katsayı) matrisinin sütunları temsil eder. Ekonomide, $r$ ve $s$ gibi herhangi iki farklı dönemde veya ülkede "j" sektöründeki üretim teknikleri aşağıdaki katsayı aracılığıyla karşılaştırılabilir;

$$
P T_{j}^{r s}=\frac{\sum_{i}\left|a_{i j}^{r}-a_{i j}^{s}\right|}{(1 / 2) \sum_{i}\left(a_{i j}^{r}+a_{i j}^{s}\right)}
$$

(2) no'lu denklemle tanımlanan söz konusu katsayı, iki dönemin veya ülkenin "j" sektörüne karşılık gelen girdi katsayıları arasındaki farkların mutlak değerlerinin toplamının, karşıııklı katsayılarının aritmetik ortalamalarının toplamına oranı $\mathrm{PT}_{\mathrm{j}}^{\text {rs şeklinde }}$ tanımlanmaktadır. $\mathrm{PT}_{j}^{\text {rs }}$ katsayısı, saf bir katsayı olup 0 ile 2 arasında değerler alabilir (Aydoğuş, 2010:139). Dönemler arasında veya ülkelere göre, teknik katsayılarda değişim, farklılık yoksa yani üretim teknikleri aynıysa payda yeralan mutlak farklar sıfır olacağından katsayı 0'a eşit çıkacaktır. Bunun anlamı dönem içinde sektörde üretim teknolojisinde hiç farklıı̆̆ın olmadığı veya her iki ülke üretim tekniğinin aynı, benzer olduğudur. Eğer teknik katsayılar iyice değiştiyse, payda da yeralan 1/2 katsayısı nedeniyle bölüm sonucu en fazla iki çıkacaktır. Bunun anlamı da, değişimin veya farklılığın çok fazla olduğudur. Bu yönüyle katsayı ne kadar 0'a yakın çıkarsa değişim, farklılık az, ne kadar 2'ye yakın çıkarsa değişim, farklıık o kadar fazla demektir. Genel olarak 0.80'nin üzerindeki oranlar farklılığın çok olduğu yönünde değerlendirilmektedirler.

\subsection{Sektörel Aramalı Kullanım Etkenliği}

Farklı dönemler arasında çeşitli aramalların kullanımındaki etkenlik dereceleri ise aşağıdaki gibi karşılaştırılabilir:

$$
I U_{i}^{r s}=\frac{\sum_{j} a_{i j}^{r} x_{j}^{s}}{\sum_{j} a_{i j}^{s} X_{j}^{s}}
$$

(3) no'lu denklemdeki $I U_{{ }_{i}}^{r s}$ katsayısı r ve s dönemlerindeki veya ülkelerindeki $i$. malının aramal olarak

kullanımındaki etkenliğin benzerlik derecesini, $X_{j}^{s}$ ise ikinci veya diğer ülke üretim vektörünü göstermektedir. Katsayının payındaki terim $r$ ülkesinde $s$ ülkesinin üretim vektörünü gerçekleştirmek için ne kadar i malının aramal olarak kullanılması gerektiğini, paydadaki terim ise $s$ ülkesinde aynı üretim vektörünü gerçekleştirebilmek için ne kadar $i$ malının aramal olarak kullanılması gerektiğini göstermektedir (Aydoğuş,2010:140). Burada doğal olarak bir oran söz konusudur. Oranın sonucu 1 ise bu dönem içerisinde veya ülkelerde sektörel bazda aramalı kullanımında farklılığın olmadığı aramalı kullanım etkenliğinin değişmediği, aynı olduğu anlamına gelmektedir. Katsayının 1'den küçük çıkması dönem içerisinde aramalı kullanımın azaldığı veya ülkede diğerine göre daha az kullanıldığı anlamına gelecek ve olumlu olarak sektörde diğer ülkeye göre aramalı kullanımında etkenliğin, verimliliğin arttığı anlamında yorumlanacaktır. Tam tersi olarak katsayının 1'den büyük çıkması diğer şartlar veriyken ilgili sektörde üretimde aragirdi kullanımının arttığı, daha çok olduğu dolayısıyla etkenliğin, verimliliğin azaldığı anlamına gelecektir.

\section{GIRDI-ÇIKTI ANALIZI YAKLAŞIMIYLA KAZAKISTAN VE TÜRKIYE EKONOMILERI}

Girdi-çıktı tabloları Türkiye'de ekonomide planlı döneme geçişle birlikte belli aralıklarla hazırlanmaktadır. Birinci beş yıllık kalkınma planına alt yapı oluşturabilmek için 1959 yılında DPT tarafından hazırlanan ilk tabloyu saymazsak, 1963 yılından beri tüm tablolar Türkiye İstatistik Kurumu tarafından hazırlanmıştır. 1968 yılı tablosu 50 sektörlü iken, 1973, 1979, 1985 ve 1990 yılı tabloları 64 sektörlüdür. 1996 ve 1998 yılı tabloları 97 ürün ve sanayi grubuna göre hazırlanmış tablolardır.

NACE (Nomenclature statistique des Activités économiques dans la Communauté Européenne) Avrupa Birliği'nce geliştirilen ekonomik faaliyetlerin istatistiki sınıflamalarını göstermek için kullanılan bir kodlama sistemidir. Ekonomideki faaliyet birimlerini oluşturan firmalara ait verilerin kategorize edilmesi için kullanılır. Bu faaliyet birimlerine ilişkin üretim sürecindeki girdi ve çıktılar, sermaye oluşumu ve finanssal işlemler gibi çeşitli istatistiklerin hazırlanması için karşılaştırılabilir homojen bir temel sağlar. Uluslararası karşılaştırılabilirliği sağlamak için de, Avrupa Birliği dahilinde kullanımı kabul edilen tanımlar, Birleşmiş Milletler Tüm Ekonomik Faaliyetlerin Uluslararası Standart Sanayi Sınıflaması (ISIC Rev.3.1) notasyonlarıyla da uyumlaştırılmıştır. Avrupa Birliği Bakanlar Konseyinin 09 Ekim 1990 tarihli kararıyla da sözkonusu sınıflamanın tüm üye ülkeler ve EFTA ülkelerinde aynı zamanda ve aynı şekilde sunulmasına ve kullanılmasına karar vermişlerdir (http://tuikapp.tuik.gov.tr/DIESS/TerminolojiListesiAction.do., 15.01.2014). 
2008 yılında yayın haline getirilen 2002 yılı tablosu ise, adı geçen "Avrupa Ekonomik Topluluğunda Faaliyete Göre Ürünlerin İstatistiki Sınıflaması (NACE Rev.1.1)"na göre 59 sanayi ve ürün grubuna göre düzenlenmiş̧ir (TÜiK, 2002 Girdi-Çıktı Sonuç Tabloları).

Kazakistan'da bağımsızlık sonrası dönemde, 1999 yılından başlanarak 2001 ve 2002 yılları hariç her yıl düzenli olarak girdi-çıktı tabloları yayınlanmıştır. 2005 yılı ve sonraki yıllarda hazırlanan tablolarda ithal yerli girdi ayrımı yer almaktadır. 2005 yılı Girdi-Çıktı tablosu 61 sektörlü tablo olarak hazırlanmışken 2006 ve sonraki yıllarda hazırlanan tablolar "Avrupa Ekonomik Topluluğunda Faaliyete Göre Ürünlerin İstatistiki Sınıflaması (NACE)"na göre 59 sektörlü tablolardır.

Çalışmada hem en son güncel durumu yansıtarak hali hazırda hazırlanan en son tablolar olma, hem de sektör sayısı, kapsam ve içerikleri bakımından aynı ilkelere göre hazırlanmış olmaları nedeniyle yayınlanmış en son tablolar olan Türkiye için 2002 yılı, Kazakistan için ise 2009 yılı Girdi-Çıktı tabloları kullanılmıştır. Her iki tablo, Uluslararası Endüstriyel Sektör Sınıflamaları (ISIC) notasyonlarına göre, sektör içerikleri bakımından incelenmiş, tüm sektörlerin her iki tabloda aynı isim, sıra ve kapsamda yeraldığı görülmüştür. Bu nedenle sektörler üzerinde herhangi bir toplulaştırmaya gidilmemiş, sadece hesaplama ve analiz kolaylığı bakımından endüstrilerarası akımda yer almayan, kişilerin doğrudan nihai kullanımlarıyla ilgili ekonomi genelinde göreli payı çok küçük olan iki sektör çıkartılarak analiz 57 üretim sektörü üzerinden yapılmıştır. Tüm hesaplamalarda; homojen üretim birimleriyle ilgili analitik amaçlı verimlilik, maliyet, işgücü gibi analizlerde kullanılan "temel fiyatlarla girdi-çıktı tablosu" kullanılmıştır.

Bunlar dışında gerek Girdi-Çıktı Analizinin teorik varsayımlarından gerekse de tabloların hazırlanma yöntemlerinden kaynaklanabilecek sektör içerikleri, enflasyonun etkisi gibi türlü sorunların olmadığı veya bunların tüm tablolarda da olması nedeniyle karşılaştırmaya dayalı sonuçları etkilemediği varsayılmıştır.

\subsection{Türkiye ve Kazakistan'ın Toplam İleri ve Geri Bağlantı Etkilerine Göre Karşılaştırılması}

Ekonomide sektörler arası ilişkileri tanımlayan temel araçlardan birisi ters matris satır ve sütun toplamlarının alınmasıyla hesaplanan toplam ileri ve geri bağlantı katsayılarıdır. Burada da, her iki ülke için toplam ileri ve geri bağlantı katsayılarıyla, bu katsayıların göreceli önemini açıklayabilmek için bağlantı endeksleri ve bunların diğer sektörlere olan yayılma dereceleri hesaplanmıştır. Elde edilen sonuçlar tablo 1 ve tablo 2'de gösterilmiştir.
Tamamı 7 tane alt sektörden oluşan Tarım ve Tarıma dayalı sanayilerde toplam ileri ve geri bağlantı etkileri incelendiğinde, ileri bağlantı etkilerinde 7-Taşocakçılığı ve diğer madencilik sektörü dışında tüm sektörlerde Kazakistan'ın ileri bağlantı etkileri mutlak olarak Türkiye'den daha büyük çıkmıştır. 1-Tarım ve avcılık ile 4-Maden kömürü linyit ve turba çıkarımı, 5-Ham petrol ve doğal gaz çıkarımı sektörlerinde katsayılar arasındaki farklar Kazakistan lehine belirgin olarak yüksektir. Bunlar dışındaki kalan sektörlerde ileri bağlantı etkileri birbirine yakın çıkmışlardır (Tablo 1.a). Sektörlerin ekonomi genelinde göreli önemini ortaya çıkarabilmek bakımından ekonomideki tüm ileri bağlantı etkilerinin ortalamasına göre hesaplanan ileri bağlantı endeksleri incelendiğinde, Türkiye için 1-Tarım ve avcılık ile 5-Ham petrol ve doğal gaz çıkarımı alt sektörlerinde endeks değerleri 1'den büyük çıkmıştır. Bu sektörler ekonomi genelinde ileri bağlantı etkilerine göre göreceli olarak ortalamanın üzerinde önemli konumdadırlar. Bunlar dışında kalan tüm tarım sektörlerinde endeks değerleri 1'den küçük çıkmış ve bu sektörlerin ekonomi genelinde göreceli konumlarının iyi olmadığı anlaşılmıştır. Kazakistan için endeks değerleri incelendiğinde, 7 alt sektörden 1- Tarım ve avcılık, 4-Maden kömürü, linyit turba çıkarımı, 5-Ham petrol doğal gaz çıkarımı ve 6-Metal cevheri madenciliği sektörlerinde endeks değerleri Türkiye aksine 1'den büyük çıkmış bu sektörlerin Kazakistan ekonomisi için Türkiye'nin aksine göreceli konumlarının daha iyi olduğu görülmüştür (Tablo 1.a).

Toplam Geri bağlantı etkileri incelendiğinde, genel olarak tüm bağlantı değerleri birbirine yakın ve aralarında çok büyük farklar olmamakla birlikte, sadece 6-Metal cevheri madenciliği sektöründe Türkiye geri bağlantı etkisi Kazakistan'dan daha yüksek çıkmış, diğer tüm sektörlerde Kazakistan değerleri Türkiye'den daha yüksek çıkmıştır. Geri bağlantı endeks değerleri bakımından ise, Türkiye için tüm alt sektörlerde endeks değerleri 1'den küçük çıkmıştır. Kazakistan'da ise, 6-Metal cevheri madenciliği ve 7-Taşocakçılığı ve diğer madencilik sektörleri dışındaki tüm sektörlerde endeks değerleri 1'den küçük çıkmıştır (Tablo 1.a). Buradan genel olarak tarıma dayalı sanayilerin her iki ülke için ekonomiyi etkileme gücünün zayıf olduğunu söyleyebiliriz.

Tamamı 29 tane alt sektörden oluşan İmalat sektörlerinde toplam ileri ve geri bağlantı etkileri incelendiğinde, 13-Ağaç ve mantar ürünleri imalatı, 16-Kok kömürü, petrol nükleer yakıt imalatı, 21-Metal eşya, 22-Makine ve Teçhizat imalatı, 28-Diğer ulaşım araçları imalatı, 30-Yeniden değerleme, 33-Inşaat olmak üzere 7 sektör dışında kalan tamamı 22 tane, tüm 
alt sektörlerde Türkiye için hesaplanan ileri bağlantı katsayıları Kazakistan'dan yüksek çıkmıştır. Ancak bu sektörlerden, 10-Tekstil, 14-Kağıt ve kağıt ürünleri, 25-Radyo, TV haberleşme cihazları imalatı, 31-Enerji, 34-Motorlu taşıtlar satış, bakım, onarım, 35-Motorlu taşıtlar dışındaki toptan ticaret ve 36-perakende ticaret sektörlerinde ileri bağlantı etkileri Türkiye lehine belirgin olarak yüksek çıkmıştır (Tablo 1.b). İleri bağlantı endeks değerlerine göre, 29 sektörden 13 tanesinde yani 10-Tekstil, 14-Kağıt ve ürünleri, 16-Kok, petrol, nükleer yakıt, 17-Kimya, 18-Plastik, 19-Mineral ürünler, 20-Ana metal sanayi, 22-Makine teçhizat, 25-Radyo, tv, 31-Enerji, 34-Motorlu taşıtlar satış ve onarımı, 35-Motorlu taşıtlar dışındaki toptan 36- perakende ticaret sektörlerinde endeks değerleri 1 'den büyük çıkmıştır. Yani bu sektörler ekonomi genelinde göreceli olarak önemli konumdadırlar. Bunlar içerisinden 14- Kağıt ve ürünleri, 16- Kok, petrol, nükleer yakıt, 17-Kimya, 19-Mineral ürünler, 20Ana metal sanayi, 22-Makine teçhizat ve 31-Enerji alt sektörlerinin endeks değerleri Kazakistan için de 1 'den büyük çıkmıştır. Yani bu sektörler her iki ülke için önemli konumdadırlar. Türkiye'den farklı olarak 8-Gıda, 21-Metal eşya, 33-inşaat sektörlerinde Kazakistan endeks değerleri 1'den büyük çıkmıştır (Tablo 1.b).

İmalat sanayinde geri bağlantı etkileri incelendiğinde, 32-Suyun toplanması, dağıtılması ile 36-Motorlu taşıtlar dışındaki perakende ticaret alt sektörleri dışındaki tüm sektörlerde Türkiye için hesaplanan geri bağlantı katsayıları Kazakistan'dan daha yüksek çıkmıştır. Genel olarak incelendiğinde, Katsayıların birbirine yakın oldukları görülmektedir. Geri bağlantı endeksleri bakımından ise, 32-Suyun toplanması ve dağıtımı, sadece Türkiye için, 34-Motorlu taşıtlar 35-Motorlu taşıtlar dışındaki toptan ticaret, 36-perakende ticaret sektörlerinde ise her iki ülke için hesaplanan endeks değerleri 1 'den küçük çıkmıştır. Bunlar dışındaki tüm imalat sektörlerinde endeks değerleri 1'den büyük veya 1'e çok yakın çıkmışlardır. Buradan genel olarak imalat sanayi alt sektörlerinin her iki ülke için göreceli öneminin korunduğunu söyleyebiliriz (Tablo 1.b).

Tamamı 21 tane alt sektörden oluşan Hizmet sektörleri için toplam ileri ve geri bağlantı etkileri incelendiğinde; ileri bağlantı etkilerine göre, 42-Posta ve Telekomünikasyon, 46-Gayrımenkul faaliyetleri, 47-Makine eşya kiralama, 48-Bilgisayar ilgili faaliyetler, 53-Sağlık işleri sosyal hizmetler olarak 5 alt sektörde Kazakistan için hesaplanan ileri bağlantı etkileri Türkiye'ninkinden daha yüksek çıkmıştır. Bunlar dışındaki tüm sektörlerde Türkiye katsayıları daha yüksektir. Ancak özellikle 38-Ka- rayolu taşımacılığı, 41-Destekleyici ulaştırma, turizm ve seyahat acentalığı, 43-Bankacılık dahil mali aracı kuruluşlar, 44-Sigortacılık, emeklilik fonları, 45-Mali kuruluşlara yardımcı faaliyetler alt sektörlerinde Türkiye lehine belirgin üstünlük vardır (Tablo 1.c). Illeri bağlantı endeksleri incelendiğinde ise, Türkiye için 38-Kara taşımacılığı, 41-Destekleyici ulaştırma, 43Mali aracı kuruluşlar, 50-Diğer iş faaliyetleri alt sektörleri dışındaki tüm sektörlerde endeks değerleri 1'den küçüktür. Kazakistan için ise, bu sektörlerden farklı olarak 42-Posta ve Telekomünikasyon alt sektöründe endeks değeri 1'den büyük çıkmıştır. Genel olarak ileri bağlantı etkilerine göre 42-Posta telekomünikasyon ve 46-Gayrı menkul faaliyetleri Kazakistan'ın Türkiye'ye göre üstün olan yönlerini oluşturmaktadır (Tablo 1.c). Geri bağlantı etkilerine göre 21 sektörden 11 tanesinde 37-Oteller lokantalar, 40-Hava yolu taşımacılığı, 41-Destekleyici ulaştırma, turizm, seyahat, 42-Posta telekomünikasyon, 43-Mali aracı kuruluşlar, 44-Sigortacılık, 45-Mali aracı kuruluşlara yardımcı faaliyetler, 47-Makine eşya kiralama, 49-ArGe hizmetleri 54-Kanalizasyon, çöp ve atıklar, 55-Diğer kuruluş faaliyetleri sektörlerinde, katsayı Türkiye lehine yüksek çıkmıştır. Endeks değerlerine göre ise, Türkiye için iki sektör 40-Hava yolu taşımacılığı ve 49-Ar-ge faaliyetleri dışındaki tüm sektörlerde endeks değerleri 1'den küçük çıkmıştır. Kazakistan için ise, 39Su yolu, 40-Hava yolu taşımacılığı, 51-Kamu yönetimi, sosyal güvenlik, 53-Sağlık işleri, 54-Kanalizasyon çöp ve atıklar, 56-Eğlence ve kültürel faaliyetler alt sektörleri dışındaki tüm sektörlerde katsayılar 1'den küçüktür (Tablo 1.c.). Buradan genel olarak her iki ülke için hizmet sektörlerinin beklendiği şekilde ekonomide göreli öneminin istenen düzeyde olmadığını belirtebiliriz.

Toplam ileri ve geri bağlantı etkilerinin daha sağlıklı değerlendirilebilmesi için her iki ülke için bu katsayıların diğer sektörlere olan yayılma dereceleri de hesaplanmıştır. Yayılma derecesi ne kadar küçük (sıfıra yakın) çıkarsa bu ilgili sektörün ekonomide o kadar çok sayıda sektörü etkilediği hatta sıfıra eşit çıkması halinde ekonomideki diğer tüm sektörleri etkilediği anlamına gelir. Burada hesaplanan yayılma derecelerine bakıldığında katsayılarının çoğunun sıfırdan çok büyük değerler olduğu görülmektedir. Buradan genel olarak her iki ülke için sektörlerin diğer sektörleri etkileme güçlerinin, diğer sektörlerle ilişkilerinin zayıf olduğunu söyleyebiliriz. Türkiye için hesaplanan ileri bağlantı yayılma derecelerine göre, tüm sonuçlar 38-Kara taşımacılığı 1,7251 ile 9-Tütün ürünleri imalatı 7,5455 arasında değişmektedir. Bu sonuca göre, yayılması en iyi olan sektör Türkiye için Karayolu taşımacılığı ulaştırma, en kötü olan ise tüt- 
üncülük sektörü olmuştur. Geri bağlantı için hesaplanan yayılma derecelerinde ise, sonuçlar 30-Yeniden değerleme 2,8788 ile 2-Ormancılık 5,9317 arasında çıkmıştır (Tablo 2).

Kazakistan için ise ileri bağlantı yayılma derecelerinde dağılım 20-Ana metal sanayi 1,7726 ile 9-Tütün ürünleri 7,5498, geri bağlantı etkilerinde, 53-Sağlık ve sosyal hizmetler 3,5462 ile 5-Hampetrol doğal gaz çıkarımı 6,1714 arasında çıkmıştır (Tablo 2). Herhangi bir sektörün diğer sektörleri etkileme derecesi her ne kadar teknolojik ilişkilere bağlı olsada aynı sektörlerde farklı katsayıların bulunmuş olmasının önemli olduğunu düşünüyoruz.

Toplam ileri ve geri bağlantı etkileri genel olarak değerlendirildiğinde, Türkiye ekonomisi için doğrudan dolaylı toplam etki 124,8371 ortalama 2,1901 , Kazakistan için toplam etki 112,8451 ortalama ise 1,9797 olarak elde edilmiştir.

\subsection{Endüstriyel Bağınlaşma Yapılarının Karşılaştırılması}

Burada hem Kazakistan hem Türkiye için sektörel ara girdi ve ara talep değerleri kullanılarak bağınlaşma katsayıları $\left(b_{j}\right)$ hesaplanmıştır. Elde edilen sonuçlar tablo 3'de görülmektedir. Sektörel aragirdi ve ara talep değerlerinin ortalamasının sektörel ara talep toplamına oranlanmasıyla elde edilen değerin toplam çıktıdaki sektör payına bölünmesiyle hesaplanan bağımlılık oranı ne kadar büyük çıkarsa ekonominin bu sektöre o kadar çok bağımlı olduğu düşünülmektedir.

Endüstriyel bağınlaşma oranlarının büyükten küçüğe sıralanmasıyla elde edilen tablo değerlerine göre; Türkiye için ekonomiye bağımlılığı en yüksek olan ilk beş sektör sırasıyla; 30-Yeniden değerleme, 23-Büro, muhasebe, bilgi işlem makinaları imalatı, 51-Kamu yönetimi savunma, sosyal güvenlik, 9-Tütün ürünleri, 54-Kanalizasyon çöp ve atıkların toplanması. Bağımlılığı en az olan son beş sektör; 35-Motorlu taşıtlar dışındaki toptan ticaret, 10-Tekstil ürünleri, 46-Gayrımenkul faaliyetleri, 38-Kara taşımacılığı, 1-Tarım ve avcllık (Tablo 3.a).

Kazakistan ekonomisi için ilk beş sektör; 12-Deri işleme ve deri ürünleri, 23-Büro, muhasebe ve bilgi işlem makinaları imalatı, 27-Motorlu kara taşıtı römork imalatı, 26-Tıbbi optik hassas aletler imalatı, 5-Ormancılık. Bağımlılığı en az olan son beş sektör; 46-Gayrımenkul faaliyetleri, 1-Tarım avcılık, 33-Inşaat, 5-Ham petrol, doğal gaz çıkarımı, 51-Kamu Yönetimi, savunma sosyal güvenlik (Tablo 3.b.).

23-Büro, muhasebe, bilgi işlem makinaları imalatı her iki ülke için bağımlıığı en çok olan ilk beş sektör içerisinde yer almıştır. 51-Kamu Yönetimi, savunma sosyal güvenlik sektörü Türkiye için ilk beş içinde yer alırken, Kazaksitan için bağımlılığı en az olan son beş içinde çıkmıştır. 1-Tarım ve avcılık her iki ülke için ekonomiye bağımlııı̆ı az olan ortak sektör olmuştur.

\section{3. Üretim Tekniklerinin Karşılaştırılması}

Girdi-Çıktı Analizinde dar anlamda sektörel üretim tekniklerini teknik katsayı matrisinin sütunları temsil etmektedir. Ülkelerarası karşılaştırmalarda, her iki ülkenin denk gelen teknik katsayıları arasındaki farkın mutlak değerinin katsayıların aritmetik ortalamasına oranlanmasıyla elde edilen katsayılarla $\left(\mathrm{PT}_{\mathrm{j}}{ }^{\mathrm{rs}}\right.$ ) üretim teknikleri birbiriyle karşılaştırılabilir. Katsayı 0 ile 2 arasında değer alabilir. Üretim tekniklerinin tamamen aynı olması durumunda teknik katsayılar birbirine eşit olacağından oran sıfır çıkacaktır. Teknik katsayılar arasındaki farklıık arttıkça oran 2'ye yaklaşacaktır. Genel olarak 0,8 civarı ve altındaki oranlarda üretim tekniklerinin benzer olduğu düşünülmektedir. Elde edilen sonuçlar tablo 4'de gösterilmiştir.

57 tane ekonomik üretim sektörü içerisinden 14 tanesinin benzerlik katsayısı 0,8 civarı veya daha küçük çıkmıştır. Üretim tekniklerinin benzer olduğu düşünülen bu sektörler; 8-Gıda, 9-Tütüncülük, 13Ağaç ve mantar ürünleri, 14-Kağıt ve kağıt ürünleri, 16-Kok, petrol ürünleri ve nükleer yakıt imalatı, 17-Kimya, 18-Plastik ve Kauçuk üretimi, 19-Mineral ürünler üretimi, 21-Metal eşya sanayi, 22-B.y.s. makine teçhizat imalatı, 24-B.y.s elektrikli makine ve cihazlar imalatı, 37-Otel-lokantalar, 43-Mali aracı kuruluşlar, 56-Eğlence, kültürel faaliyetler (Tablo 4). Buradan genel olarak iki ülke ekonomisinin farklı tekniklerle üretim yaptığını belirtebiliriz.

\subsection{Aramalı Kullanımı Etkenlik Derecelerinin Karşılaştırılması}

Endüstrilerarası analizde ekonomik sektörler aramalı kullanımları bakımından da incelenebilirler. Bu inceleme aynı ekonomik sektörlerin farklı dönemlerde incelenmesi şeklinde olabileceği gibi, aynı dönemde farklı ülkelere ait tabloların incelenmesiyle de yapılabilir. Burada da Kazakistan ve Türkiye ekonomileri aramalı kullanımı açısından da değerlendirilmektedirler. Önce Türkiye ekonomisi üretim vektörü Türkiye ekonomisine ait teknik katsayı matrisiyle çarpılarak, üretimi gerçekleştirebilmek için gerekli sektörel aramalı kullanımları hesaplanmıştır. Sonra aynı üretim Kazakistan'da yapılsaydı aramalı kullanımı ne olurdu? sorusunun yanıtını verecek şekilde Türkiye ekonomisi üretim vektörü Kazakistan ekonomisi teknik katsayı matrisiyle çarpılarak sektörel ara malı kullanımları hesaplanmıştır. Elde edilen aramalı kullanımları birbirine oranlanarak etkenlik dereceleri elde edilmiştir. Küçükten büyüğe sıralanmış sonuçlar tablo 5'te görülmektedir. 
Örneğin, 1-Tarım avcılık sektörü için hesaplanan oran $0,8252 \quad(28.983 .704 / 35 \cdot 121.343=0,8252) \quad$ çıkmıștır. Üretim Türkiye'de gerçekleştirildiğinde kullanılan aramalı miktarı 28.983.704 olmaktadır. Aynı üretim Kazakistan'da gerçekleştirildiğinde kullanılan aragirdi miktarı 35.121.343 olmaktadır. Bu durumda Türkiye aynı üretimi daha az ara girdi kullanımıyla gerçekleştirmekte dolayısıyla kaynakları Kazakistan'a göre daha etkin kullanmaktadır. Oran sonuçlarına göre, 1'den küçük sonuçlar Türkiye'nin etkinliğinin Kazakistan'a göre daha iyi olduğu, 1'den büyük sonuçlar ise, Kazakistan'ın etkinliğnin Türkiye'ye göre daha iyi olduğu anlamına gelmektedir. Ekonomi genelinde yer alan 57 sektörden 23 tanesinde oran 1'den küçük çıkmıştır. Bu sektörler sırasıyla; 16Kok kömürü, petrol ürünleri ve nükleer yakıt imalatı, 8-Gıda, 14-Kağıt ve kağıt ürünleri, 21-Metal eşya, 24-Elektrikli makinalar, 9- Tütün, 22-B.y.s. Makine ve teçhizat, 37-Otel-lokantalar, 19-Mineral ürünler, 18-Plastik, 43-Mali aracı kuruluşlar, 13-Ağaç mantar ürünleri, 17-Kimya, 27-Motorlu kara taşıtları, 1-Tarım avcılık, 10-Tekstil, 56-Eğlence, kültürel faaliyetler, 7-Taşocakçılığı, diğer madencilik, 35-Motorlu taşıtlar dışı toptan ticaret, 42-Posta telekomünikasyon, 46-Gayrımenkul faaliyetleri şeklindedir. Bu sektörlerde Türkiye'nin Kazakistan'a göre daha verimli olduğunu aragirdi kullanımında daha etkin olduğunu söyleyebiliriz. Söz konusu sektörler genel olarak incelendiğinde, bazı imalat sektörleriyle, turizm, otelcilik, eğlence gibi hizmet sektörlerinde Türkiye'nin daha avantajlı olduğu görülmektedir. Bu etkenlik hem Türkiye hem Kazakistan açısından maliyet avantajına dönüştürüldüğünde iki ülke yararına ekonomik işbirliği ve ticaretin gelişmesine katkı sağlayabilir.

\section{SONUÇ}

Ulaşım, iletişim ve üretim alanında gerçekleşen teknolojik gelişmeler ülkeler arasındaki coğrafi sınırların ortadan kalkmasına rekabetin dünya geneline yayılmasına yol açmış, artan rekabet benzer kültüre ve yakın coğrafyalara sahip ülkelerin bir araya gelmelerini zorunlu hale getirmiştir. Artık günümüzde gelişmiş ve gelişmekte olan tüm ülkeler rekabetin olumsuz etkilerinden korunabilmek ve ekonomik büyüme ve kalkınmalarını gerçekleştirebilmek için ekonomik birlikleri oluşturarak birlikte hareket eder hale gelmişlerdir. Bu yönüyle ülkeler arasında ekonomik işbirliğini arttıracak plan ve politikaların hazırlanarak hızla uygulamaya geçilmesi kaçınılmaz hale gelmiştir.

1990 sonrası dönemde eski Sovyetler birliğinin dağılmasıyla ortaya çıkan Orta Asya Türk Cumhuriyetlerine tarihten gelen ortak bağlar ve kültürel özellikler nedeniyle ülkemiz özel bir ilgi göstermektedir. Kazakistan Orta Asya Türk Cumhuriyetleri içerisinde zengin petrol ve doğal gaz yataklarına sahip ekonomik yönden zengin ülkelerden birisidir. Kuşkusuz iki üke arasındaki ekonomik işbirliğinin ve ticari ilişkilerin geliştirilmesi başta Türkiye Kazakistan olmak üzere tüm bölge ülkeleri için önemli kazançların ortaya çıkmasına yol açacaktır. Bu düşüncelerle Türkiye ve Kazakistan ekonomilerinin karşılaştırmalı olarak incelemesi yapılmıştır. Söz konusu inceleme girdi-çıktı analizi yaklaşımıyla gerçekleştirilmiştir. Her iki ülkede aynı sektör sayısı ve kapsamda en son hazırlanan 2002 ve 2009 yılı girdi-çıktı sonuç tabloları kullanılmıştır. İki ülke ekonomisinin karşılaştırılması ekonomideki toplam bağlantı etkilerinin karşılaştırılması, endüstriyel bağınlaşma oranlarının hesaplanması, üretim tekniklerinin benzerliğinin araştırılması ve aramalı kullanım etkinliğinin incelenmesiyle gerçekleştirilmiştir.

Illeri ve geri bağlantı etkilerine göre, tarım ve tarıma dayalı primer üretim sektörlerinin her iki ülke için ekonomiyi etkileme gücünün zayıf olduğu anlaşıımıştır. İmalat sektörlerinde yer alan 22 alt sektörün hepsinde Türkiye için hesaplanan ileri bağlantı katsayıları Kazakistan'dan yüksektir. Ancak bu sektörlerden, 10-Tekstil, 14-Kağıt ve kağıt ürünleri, 25-Radyo, TV haberleşme cihazları imalatı, 31-Enerji, 34-Motorlu taşıtlar satış, bakım, onarım, 35-Motorlu taşıtlar dışındaki toptan ticaret ve 36-perakende ticaret sektörlerinde ileri bağlantı etkileri Türkiye lehine belirgin olarak yüksek çıkmıştır.

Toplam geri bağlantı etkileri genel olarak incelendiğinde, imalat sanayinde tüm katsayıların birbirine yakın oldukları görülmüştür. Bağlantı etkilerinin endeks değerlerine bakıldığında, 14- Kağıt ve ürünleri, 16- Kok, petrol, nükleer yakıt, 17-Kimya, 19-Mineral ürünler, 20-Ana metal sanayi, 22-Makine teçhizat ve 31-Enerji alt sektörlerinin endeks değerleri hem Kazakistan hem Türkiye için 1'den büyük çıkmıştır. Yani bu sektörler her iki ülke için ekonomi genelinde göreceli olarak önemli konumda çıkan sektörler olmuşlardır. Endeks değerleri her iki ülke için birbirine yakın çıkmıştır. Buradan genel olarak imalat sanayi alt sektörlerinin her iki ülke için göreceli öneminin korunduğunu söyleyebiliriz. Hizmet sektörleri için ileri ve geri bağlantı etkileri incelendiğinde, her iki ülke için hizmet sektörlerinin ekonomide göreli öneminin istenen düzeyde olmadığı anlaşılmıştır.

Yayılma dereceleri bakımından her iki ülke için ekonomik sektörlerin diğer sektörleri etkileme güçlerinin, diğer sektörlerle ilişkilerinin zayıf olduğu görülmüştür. Toplam ileri ve geri bağlantı etkileri genel olarak değerlendirildiğinde, Türkiye ekonomisi için doğrudan dolaylı toplam etki 124,8371 ortalama 2,1901 , Kazakistan için toplam etki 112,8451 ortala- 
ma ise 1,9797 olarak elde edilmiştir. Türkiye'deki ekonomik üretim sektörleri Kazakistan'a göre ekonomiyi daha çok etkileme potansiyeline sahiptir.

Sektörel üretim tekniklerinin karşılaştırılmasında, 57 tane ekonomik üretim sektörü içerisinden 14 tanesinin benzerlik katsayısı 0,8 civarı veya daha küçük çıkmıştır. Buradan genel olarak iki ülke ekonomisinin farklı tekniklerle üretim yaptığını belirtebiliriz.

Aramalı kullanımlarının etkenlik derecelerinin karşılaştııılmasında, ekonomi genelinde yeralan 57 sektörden 23 tanesinde oran 1'den küçük çıkmıştır. Türkiye'nin göreli olarak kaynakları daha etkin kullandığı 1 'den küçük katsayıların elde edildiği sözkonusu sektörler genel olarak incelendiğinde, bazı imalat sektörleriyle, turizm, otelcilik, eğlence gibi hizmet sektörlerinde Türkiye'nin daha avantajlı olduğu görülmüştür.
Elde edilen sonuçlara göre, İmalat sektörlerinde Türkiye'nin göreli olarak daha avantajlı olduğu görülmektedir. Kazakistan'ın genelde hammadde ve yarımamul ihracatçısı olması ve başta buğday olmak üzere bölgede hububat ihracatçısı konumunda ön sıralarda yeralması bu sonucu desteklemektedir. Bu yönüyle Türkiye'nin daha çok tekstil, gıda, kağıt otomotiv alanlarında işlenmiş ürünleri ihrac etmesi hizmet sektörleriyle ilgili olarak destekleyici ulaştırma seyahat ve turizm alanında işbirliğini geliştirmesi uygun olacaktır. Tüm burada ulaşılan sonuçların hem Türkiye hem Kazakistan açısından maliyet avantajına dönüştürülmesi halinde iki ülke yararına ekonomik işbirliği ve ticaretin gelişmesine katkı sağlayabileceği düşünülmektedir.

\section{SON NOTLAR}

Söz konusu makale 26 - 28.06.2013 tarihleri arasında Kırgızistan-Türkiye Manas Üniversitesi İİBF, Finans ve Bankacılık Bölümü tarafından düzenlenen Uluslararası Ekonomi, Finans ve Bankacılık Konferansı'nda sunulmuştur.

\section{KAYNAKLAR}

The Economist Intelligence Unit (January 2010) Kazakhstan Country Report.

TÜİK, http://www.tuik.gov.tr/UstMenu. do?metod=temelist, (17.05.2012).

İGEME İhracatı Geliştirme Etüd Merkezi (2011), Somuncuoğlu, T., Kazakistan Ülke Raporu, Ankara. http://www.een.kso.org.tr/up/dene/Kazakistan_ulke_ raporu_2011.pdf, (15.01.2014)

Todaro, M.P. (1987) Kalkınma Planlaması Modeller ve Yöntemler, İstanbul.
Aydoğuş, O. (2010) Girdi-Çıktı Modellerine Giriş, Ankara, Efil Yayınevi.

TÜİK (2010) 2002 Yılı Girdi-Çıktı Sonuç Tabloları, Ankara.

Агентство Республики Казахстан по статистике (2009) 'Таблицы «Затраты-Выпуск» Республики Казахстан за 2009 г” www.stat.gov.kz

TÜİK, http://tuikapp.tuik.gov.tr/DIESS/TerminolojiListesiAction.do, (15.01.2014). 


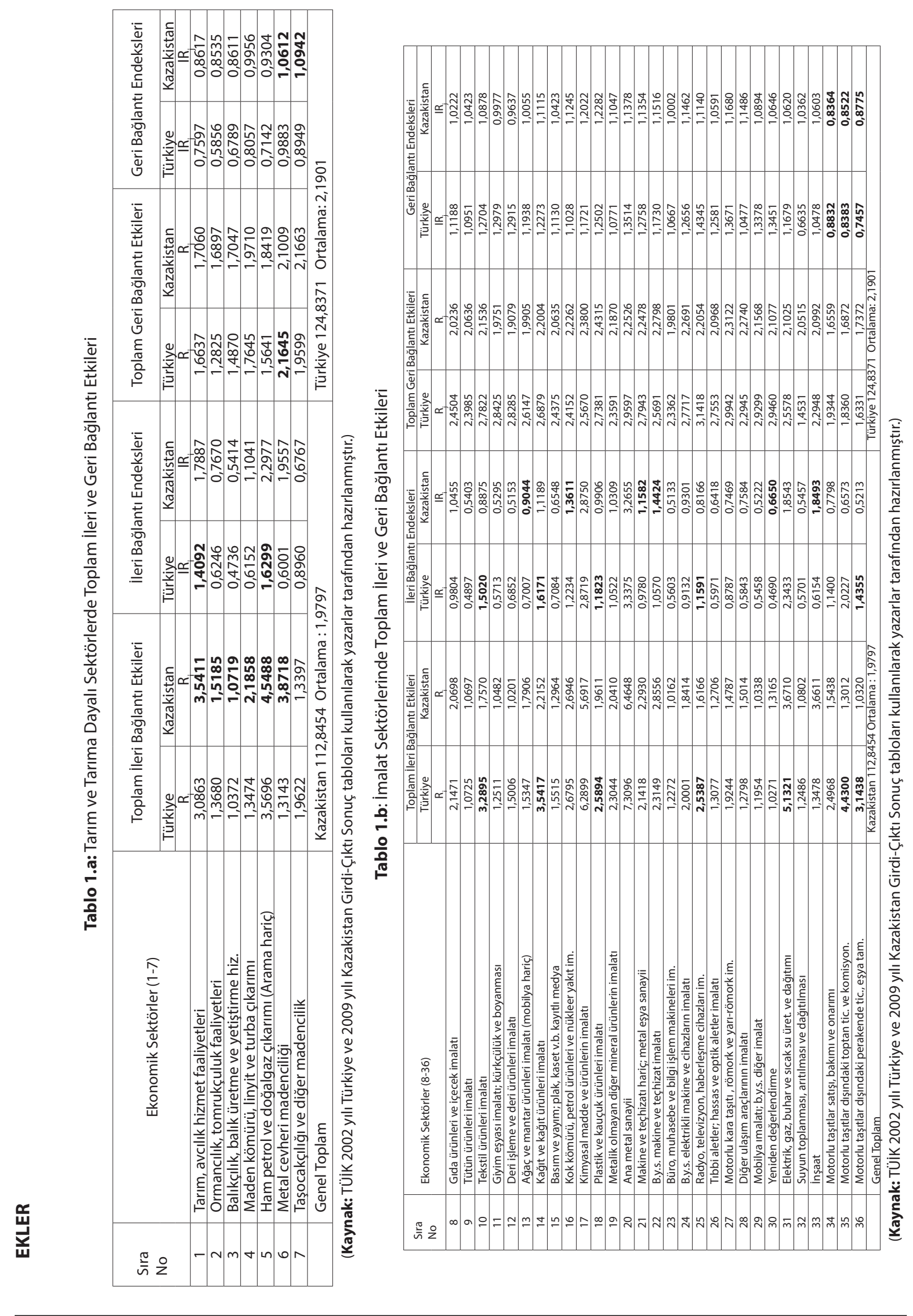




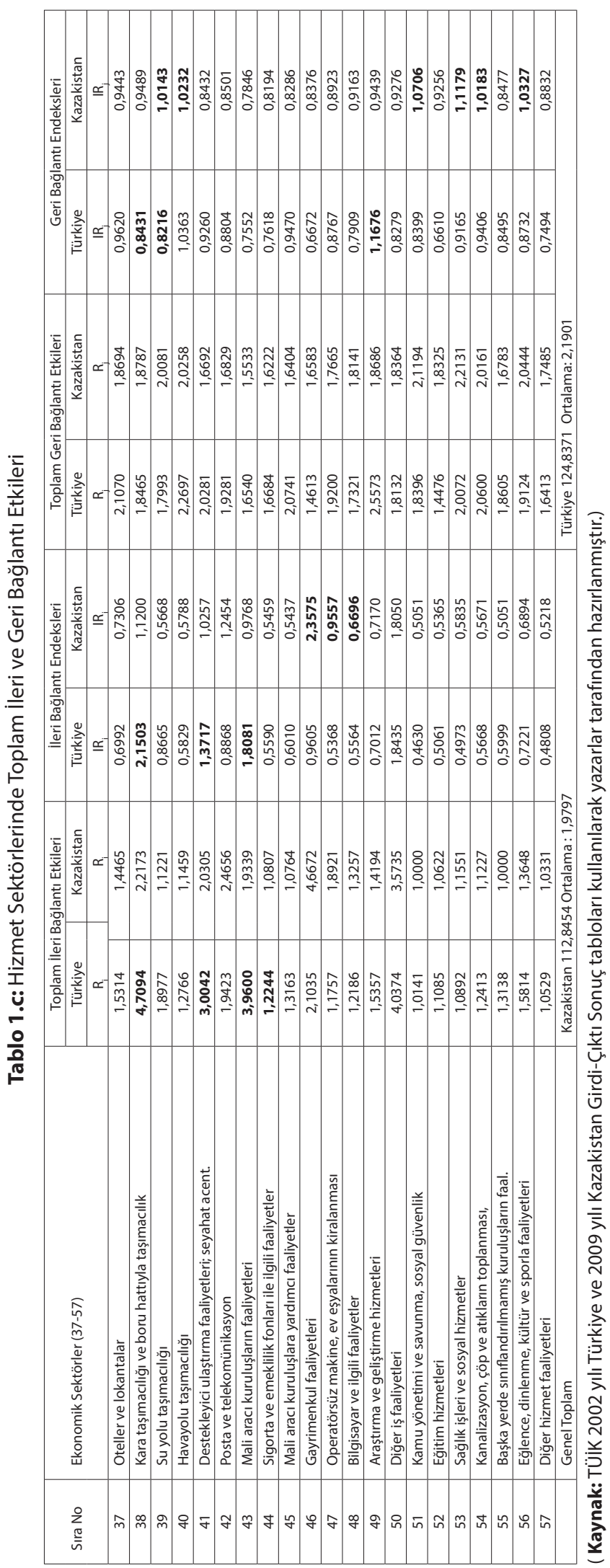


Tablo 2: Illeri ve Geri Bağlantı Yayılma Dereceleri

\begin{tabular}{|c|c|c|c|c|c|}
\hline \multirow{3}{*}{$\begin{array}{l}\text { Sira } \\
\text { No }\end{array}$} & \multirow{3}{*}{ Ekonomik Sektörler } & \multicolumn{2}{|c|}{$\begin{array}{c}\text { Toplam İleri Bağlantı Yayılma } \\
\text { Dereceleri }\end{array}$} & \multicolumn{2}{|c|}{$\begin{array}{c}\text { Toplam Geri Bağlantı Yayılma } \\
\text { Dereceleri }\end{array}$} \\
\hline & & Türkiye & Kazakistan & Türkiye & Kazakistan \\
\hline & & $\mathrm{R}$ & $\mathrm{R}$ & $\mathrm{R}$ & $\mathrm{R}_{\mathrm{f}}$ \\
\hline 1 & Tarım, avcılık hizmet faaliyetleri & 3,1892 & 3,1978 & 5,3926 & 6,0411 \\
\hline 2 & Ormancılık, tomrukçuluk faaliyetleri & 5,6056 & 6,5792 & 5,9317 & 5,9074 \\
\hline 3 & Balıkçıık, balık üretme ve yetiştirme hiz. & 7,4133 & 7,3443 & 5,1518 & 4,6061 \\
\hline 4 & Maden kömürü, linyit ve turba çıkarımı & 5,6709 & 3,6624 & 4,3398 & 4,0957 \\
\hline 5 & Ham petrol ve doğalgaz çıkarımı (Arama hariç) & 2,4835 & 2,8544 & 4,9814 & 6,1714 \\
\hline 6 & Metal cevheri madenciliği & 5,7807 & 2,3034 & 3,5344 & 4,1299 \\
\hline 7 & Taşocakçılığı ve diğer madencilik & 4,0749 & 5,8587 & 4,0692 & 3,6786 \\
\hline 8 & Gıda ürünleri ve içecek imalatı & 4,2423 & 4,0783 & 3,9472 & 4,3847 \\
\hline 9 & Tütün ürünleri imalatı & 7,5455 & 7,5498 & 3,4760 & 4,0434 \\
\hline 10 & Tekstil ürünleri imalatı & 3,8035 & 5,1156 & 4,2082 & 4,1757 \\
\hline 11 & Giyim eşyası imalatı; kürkçülük ve boyanması & 6,3949 & 7,2752 & 3,3024 & 4,0011 \\
\hline 12 & Deri işleme ve deri ürünleri imalatı & 6,9786 & 7,5295 & 3,7393 & 4,3318 \\
\hline 13 & Ağaç ve mantar ürünleri imalatı (mobilya hariç) & 5,8220 & 5,4215 & 3,4777 & 4,8348 \\
\hline 14 & Kağıt ve kağıt ürünleri imalatı & 3,0382 & 4,4720 & 3,8627 & 4,4890 \\
\hline 15 & Basım ve yayım; plak, kaset v.b. kayıtlı medya & 5,0506 & 6,3505 & 3,3824 & 4,1067 \\
\hline 16 & Kok kömürü, petrol ürünleri ve nükleer yakıt im. & 3,0253 & 2,8168 & 3,8517 & 4,6308 \\
\hline 17 & Kimyasal madde ve ürünlerin imalatı & 1,7575 & 2,0592 & 4,1395 & 4,4740 \\
\hline 18 & Plastik ve kauçuk ürünleri imalatı & 3,2433 & 4,0502 & 3,3410 & 3,8987 \\
\hline 19 & Metalik olmayan diğer mineral ürünlerin imalatı & 3,8074 & 4,2882 & 3,7565 & 4,0558 \\
\hline 20 & Ana metal sanayii & 2,0181 & 1,7726 & 4,4647 & 4,7262 \\
\hline 21 & Makine ve teçhizatı hariç; metal eșya sanayii & 3,7637 & 3,4551 & 3,3296 & 3,8382 \\
\hline 22 & B.y.s. makine ve techizat imalatı & 3,6689 & 2,9312 & 3,5193 & 3,8993 \\
\hline 23 & Büro, muhasebe ve bilgi işlem makineleri im. & 6,5881 & 7,4802 & 3,5124 & 4,1751 \\
\hline 24 & B.y.s. elektrikli makine ve cihazların imalatı & 4,4353 & 5,2443 & 3,3156 & 4,3919 \\
\hline 25 & Radyo, televizyon, haberleşme cihazları im. & 5,0722 & 6,3030 & 4,0800 & 4,7070 \\
\hline 26 & Tıbbi aletler; hassas ve optik aletler imalatı & 6,7518 & 6,2955 & 3,2623 & 3,9007 \\
\hline 27 & Motorlu kara taşıtı, römork ve yarı-römork im. & 5,0848 & 5,4390 & 3,4080 & 3,6848 \\
\hline 28 & Diğer ulaşım araçlarının imalatı & 6,3092 & 5,2774 & 3,5672 & 3,6717 \\
\hline 29 & Mobilya ımalatı; b.y.s. diğer imalat & 6,4407 & 7,3263 & 2,9484 & 3,6464 \\
\hline 30 & Yeniden değerlendirme & 7,3722 & 5,9482 & 2,8788 & 3,9202 \\
\hline 31 & Elektrik, gaz, buhar ve sıcak su üret. ve dağıtımı & 2,5006 & 2,2904 & 5,1549 & 4,0100 \\
\hline 32 & Suyun toplanması, arıtılması ve dağıtılması & 6,0360 & 7,0081 & 5,1925 & 3,8340 \\
\hline 33 & İnsaat & 5,7017 & 2,5229 & 3,4026 & 4,3934 \\
\hline 34 & Motorlu taşıtlar satışı, bakımı ve onarımı & 3,1419 & 4,9244 & 4,1133 & 4,6552 \\
\hline 35 & Motorlu taşıtlar dışında toptan tic. ve komisyon. & 1,7412 & 5,9672 & 4,2951 & 4,6142 \\
\hline 36 & Motorlu taşıtlar dışında perakende tic., eşya tam. & 2,3913 & 7,3272 & 4,6619 & 4,3386 \\
\hline 37 & Oteller ve lokantalar & 4,9196 & 5,2399 & 3,6617 & 4,1786 \\
\hline 38 & Kara taşımacılığı ve boru hattıyla tassımacılık & 1,7251 & 3,4299 & 4,5490 & 4,0750 \\
\hline 39 & Su yolu taşımacılığı & 4,3438 & 6,8398 & 4,6336 & 4,0226 \\
\hline 40 & Havayolu taşımacılığı & 6,1320 & 6,5882 & 3,5470 & 3,7723 \\
\hline 41 & Destekleyici ulaştırma faaliyetleri; seyahat acent. & 3,1938 & 3,8012 & 4,7539 & 4,6388 \\
\hline 42 & Posta ve telekomünikasyon & 4,0750 & 3,1555 & 4,1659 & 4,5891 \\
\hline 43 & Mali aracı kuruluşların faaliyetleri & 2,1028 & 4,2344 & 5,0182 & 5,3117 \\
\hline 44 & Sigorta ve emeklilik fonları ile ilgili faaliyetler & 6,1685 & 6,9801 & 4,5569 & 4,6441 \\
\hline 45 & Mali aracı kuruluşlara yardımcı faaliyetler & 6,1958 & 7,0168 & 4,0007 & 4,5985 \\
\hline 46 & Gayrimenkul faaliyetleri & 3,5716 & 1,8272 & 5,1946 & 4,6166 \\
\hline 47 & Operatörsüz makine, ev essyalarının kiralanması & 6,4681 & 4,3245 & 3,9623 & 4,3710 \\
\hline 48 & Bilgisayar ve ilgili faaliyetler & 6,2262 & 5,8697 & 4,3926 & 4,3789 \\
\hline 49 & Arastırma ve geliștirme hizmetleri & 4,9474 & 5,3515 & 3,0297 & 4,1693 \\
\hline 50 & Diğer iş faaliyetleri & 1,9477 & 2,6001 & 4,4259 & 5,0666 \\
\hline 51 & Kamu yönetimi ve savunma, sosyal qüvenlik & 7,4565 & 7,5498 & 4,0792 & 3,5702 \\
\hline 52 & Eğitim hizmetleri & 6,8349 & 7,1140 & 5,2146 & 4,1259 \\
\hline 53 & Sağlık işleri ve sosyal hizmetler & 7,1252 & 6,5810 & 3,8596 & 3,5462 \\
\hline 54 & Kanalizasyon, çöp ve atıkların toplanması, & 7,4655 & 6,9441 & 4,5184 & 3,8931 \\
\hline 55 & Başka yerde sınıflandırılmamış kuruluşların faal. & 6,6480 & 7,5498 & 4,7030 & 4,5510 \\
\hline 56 & Eğlence, dinlenme, kültür ve sporla faaliyetleri & 5,6497 & 6,2578 & 4,6601 & 4,1829 \\
\hline 57 & Diğer hizmet faaliyetleri & 7,3371 & 7,3056 & 4,7004 & 4,4147 \\
\hline
\end{tabular}

(Kaynak: TÜIK 2002 yılı Türkiye ve 2009 yılı Kazakistan Girdi-Çıktı Sonuç tabloları kullanılarak yazarlar tarafından hazırlanmıştır. ) 
Tablo 3.a: Türkiye Ekonomisi İçin Büyükten Küçüğe

Sıralanmış Endüstriyel Bağınlaşma Oranları (b)

\begin{tabular}{|c|c|c|}
\hline $\begin{array}{l}\text { Sira } \\
\text { No }\end{array}$ & Ekonomik Sektörler & Türkiye (2002) \\
\hline 30 & Yeniden değerlendirme & $12.486,2$ \\
\hline 23 & Büro, muhasebe ve bilgi işlem makineleri im. & $2.109,973$ \\
\hline 51 & Kamu yönetimi ve savunma, sosyal güvenlik & $1.506,357$ \\
\hline 9 & Tütün ürünleri imalatı & $1.423,144$ \\
\hline 54 & Kanalizasyon, çöp ve atıkların toplanması, & $1.175,991$ \\
\hline 6 & Metal cevheri madenciliği & 878,1568 \\
\hline 26 & Tıbbi aletler; hassas ve optik aletler imalatı & 842,0731 \\
\hline 3 & Balıkçılık, balık üretme ve yetiştirme hiz. & 680,4764 \\
\hline 57 & Diğer hizmet faaliyetleri & 640,2914 \\
\hline 47 & Operatörsüz makine, ev eşyalarının kiralanması & 557,0372 \\
\hline 45 & Mali aracı kuruluşlara yardımcı faaliyetler & 478,9518 \\
\hline 5 & Ham petrol ve doğalgaz çıkarımı (Arama hariç) & 425,782 \\
\hline 44 & Sigorta ve emeklilik fonları ile ilgili faaliyetler & 423,8201 \\
\hline 49 & Araştırma ve geliştirme hizmetleri & 387,9337 \\
\hline 28 & Diğer ulaşım araçlarının imalatı & 370,1092 \\
\hline 2 & Ormancılık, tomrukçuluk faaliyetleri & 352,2038 \\
\hline 53 & Sağlık işleri ve sosyal hizmetler & 345,3505 \\
\hline 48 & Bilgisayar ve ilgili faaliyetler & 334,9682 \\
\hline 4 & Maden kömürü, linyit ve turba çıkarımı & 245,7277 \\
\hline 29 & Mobilya ımalatı; b.y.s. diğer imalat & 244,5758 \\
\hline 12 & Deri işleme ve deri ürünleri imalatı & 243,7674 \\
\hline 13 & Ağaç ve mantar ürünleri imalatı (mobilya hariç) & 235,123 \\
\hline 40 & Havayolu taşımacılığı & 196,2897 \\
\hline 7 & Taşocakçılığı ve diğer madencilik & 186,1143 \\
\hline 15 & Basım ve yayım; plak, kaset v.b. kayıtlı medya & 183,6322 \\
\hline 32 & Suyun toplanması, arıtılması ve dağıtılması & 173,801 \\
\hline 55 & Başka yerde sınıflandırılmamış kuruluşların faal. & 165,6665 \\
\hline 25 & Radyo, televizyon, haberleşme cihazları im. & 161,2804 \\
\hline 56 & Eğlence, dinlenme, kültür ve sporla faaliyetleri & 144,7967 \\
\hline 52 & Eğitim hizmetleri & 143,5979 \\
\hline 11 & Giyim eşyası imalatı; kürkçülük ve boyanması & 141,4986 \\
\hline 24 & B.y.s. elektrikli makine ve cihazların imalatı & 111,2718 \\
\hline 37 & Oteller ve lokantalar & 98,86998 \\
\hline 14 & Kağıt ve kağıt ürünleri imalatı & 97,04028 \\
\hline 39 & Su yolu taşımacılığı & 91,71024 \\
\hline 21 & Makine ve teçhizatı hariç; metal eşya sanayii & 82,99176 \\
\hline 27 & Motorlu kara taşıtı, römork ve yarı-römork im. & 80,39095 \\
\hline 33 & İnşaat & 76,84078 \\
\hline 18 & Plastik ve kauçuk ürünleri imalatı & 70,26683 \\
\hline 16 & Kok kömürü, petrol ürünleri ve nükleer yakıt im. & 67,96176 \\
\hline 22 & B.y.s. makine ve teçhizat imalatı & 62,35873 \\
\hline 42 & Posta ve telekomünikasyon & 61,17821 \\
\hline 19 & Metalik olmayan diğer mineral ürünlerin imalatı & 53,95385 \\
\hline 34 & Motorlu taşıtlar satışı, bakımı ve onarımı & 39,70886 \\
\hline 41 & Destekleyici ulaştırma faaliyetleri; seyahat acent. & 37,83194 \\
\hline 20 & Ana metal sanayii & 34,55329 \\
\hline 31 & Elektrik, gaz, buhar ve sıcak su üret. ve dağıtımı & 32,06813 \\
\hline 17 & Kimyasal madde ve ürünlerin imalatı & 30,47894 \\
\hline 50 & Diğer iş faaliyetleri & 28,04127 \\
\hline 8 & Gıda ürünleri ve içecek imalatı & 25,90429 \\
\hline 43 & Mali aracı kuruluşların faaliyetleri & 23,4198 \\
\hline 36 & Motorlu taşıtlar dışında kalan perakende ticaret, eşya tam. & 21,26563 \\
\hline 35 & Motorlu taşıtlar dışında kalan toptan ticaret ve komisyon. & 19,74571 \\
\hline 10 & Tekstil ürünleri imalatı & 19,57684 \\
\hline 46 & Gayrimenkul faaliyetleri & 18,81254 \\
\hline 38 & Kara taşımacılığı ve boru hattıyla taşımacılık & 13,41521 \\
\hline 1 & Tarım, avcılık hizmet faaliyetleri & 10,20783 \\
\hline
\end{tabular}

(Kaynak: TÜIK 2002 yılı Türkiye ve 2009 yılı Kazakistan Girdi-Çıktı Sonuç tabloları kullanılarak yazarlar tarafından hazırlanmıştır.) 
Tablo 3.b:Kazakistan Ekonomisi İçin Büyükten Küçüğe Sıralanmış Endüstriyel Bağınlaşma Oranları (bj)

\begin{tabular}{|c|c|c|}
\hline $\begin{array}{l}\text { Sira } \\
\text { No }\end{array}$ & Ekonomik Sektörler & $\begin{array}{c}\text { Kazakistan } \\
\text { (2009) }\end{array}$ \\
\hline 12 & Deri işleme ve deri ürünleri imalatı & 6810,199 \\
\hline 23 & Büro, muhasebe ve bilgi işlem makineleri im. & 6735,203 \\
\hline 27 & Motorlu kara taşıtı , römork ve yarı-römork im. & 2502,394 \\
\hline 26 & Tıbbi aletler; hassas ve optik aletler imalatı & 2423,174 \\
\hline 2 & Ormancılık, tomrukçuluk faaliyetleri & 2379,194 \\
\hline 29 & Mobilya ımalatı; b.y.s. diğer imalat & 2163,239 \\
\hline 25 & Radyo, televizyon, haberleşme cihazları im. & 2143,24 \\
\hline 9 & Tütün ürünleri imalatı & 2084,221 \\
\hline 11 & Giyim eşyası imalatı; kürkçülük ve boyanması & 1706,53 \\
\hline 3 & Balıkçılık, balık üretme ve yetiştirme hiz. & 1417,576 \\
\hline 13 & Ağaç ve mantar ürünleri imalatı (mobilya hariç) & 1229,614 \\
\hline 39 & Su yolu taşımacılığı & 1055,888 \\
\hline 32 & Suyun toplanması, arıtılması ve dağıtılması & 1027,152 \\
\hline 14 & Kağıt ve kağıt ürünleri imalatı & 808,3204 \\
\hline 10 & Tekstil ürünleri imalatı & 766,5143 \\
\hline 57 & Diğer hizmet faaliyetleri & 667,5143 \\
\hline 45 & Mali aracı kuruluşlara yardımcı faaliyetler & 522,855 \\
\hline 30 & Yeniden değerlendirme & 519,8904 \\
\hline 54 & Kanalizasyon, çöp ve atıkların toplanması, & 495,3263 \\
\hline 24 & B.y.s. elektrikli makine ve cihazların imalatı & 433,5341 \\
\hline 36 & Motorlu taşıtlar dışında kalan perakende ticaret, eşya tam. & 406,1415 \\
\hline 40 & Havayolu taşımacılığı & 339,785 \\
\hline 7 & Taşocakçılığı ve diğer madencilik & 338,8773 \\
\hline 52 & Eğitim hizmetleri & 336,1648 \\
\hline 15 & Basım ve yayım; plak, kaset v.b. kayıtlı medya & 329,447 \\
\hline 53 & Sağlık işleri ve sosyal hizmetler & 304,5984 \\
\hline 44 & Sigorta ve emeklilik fonları ile ilgili faaliyetler & 298,6567 \\
\hline 18 & Plastik ve kauçuk ürünleri imalatı & 290,8144 \\
\hline 48 & Bilgisayar ve ilgili faaliyetler & 237,893 \\
\hline 56 & Eğlence, dinlenme, kültür ve sporla faaliyetleri & 227,0608 \\
\hline 49 & Araştırma ve geliştirme hizmetleri & 203,7188 \\
\hline 28 & Diğer ulaşım araçlarının imalatı & 160,5813 \\
\hline 17 & Kimyasal madde ve ürünlerin imalatı & 154,3685 \\
\hline 21 & Makine ve teçhizatı hariç; metal eşya sanayii & 147,7533 \\
\hline 22 & B.y.s. makine ve teçhizat imalatı & 142,9432 \\
\hline 47 & Operatörsüz makine, ev eşyalarının kiralanması & 141,2612 \\
\hline 19 & Metalik olmayan diğer mineral ürünlerin imalatı & 123,454 \\
\hline 37 & Oteller ve lokantalar & 100,1621 \\
\hline 34 & Motorlu taşıtlar satışı, bakımı ve onarımı & 99,47847 \\
\hline 4 & Maden kömürü, linyit ve turba çıkarımı & 93,65354 \\
\hline 16 & Kok kömürü, petrol ürünleri ve nükleer yakıt im. & 42,8301 \\
\hline 31 & Elektrik, gaz, buhar ve sıcak su üret. ve dağıtımı & 40,18361 \\
\hline 8 & Gıda ürünleri ve içecek imalatı & 40,07986 \\
\hline 35 & Motorlu taşıtlar dişında kalan toptan ticaret ve komisyon. & 38,9513 \\
\hline 6 & Metal cevheri madenciliği & 38,22649 \\
\hline 42 & Posta ve telekomünikasyon & 37,73308 \\
\hline 41 & Destekleyici ulaştırma faaliyetleri; seyahat acent. & 34,83503 \\
\hline 38 & Kara taşımacılığı ve boru hattıyla taşımacılık & 28,59836 \\
\hline 43 & Mali aracı kuruluşların faaliyetleri & 27,60431 \\
\hline 20 & Ana metal sanayii & 19,88157 \\
\hline 50 & Diğer iş faaliyetleri & 19,786 \\
\hline 46 & Gayrimenkul faaliyetleri & 15,74022 \\
\hline 1 & Tarım, avcılık hizmet faaliyetleri & 14,79923 \\
\hline 33 & İnşaat & 11,86144 \\
\hline 5 & Ham petrol ve doğalgaz çıkarımı (Arama hariç) & 6,200049 \\
\hline 51 & Kamu yönetimi ve savunma, sosyal güvenlik & 0,000 \\
\hline 55 & Başka yerde sınıflandırılmamış kuruluşların faal. & 0,000 \\
\hline
\end{tabular}

(Kaynak: TÜiK 2002 yılı Türkiye ve 2009 yılı Kazakistan Girdi-Çıktı Sonuç tabloları kullanılarak yazarlar tarafından hazırlanmıştır.) 
Tablo 4: Türkiye ve Kazakistan Ekonomilerinin Üretim Tekniklerinin Benzerliği

\begin{tabular}{|c|c|c|}
\hline $\begin{array}{l}\text { Sira } \\
\text { No }\end{array}$ & Ekonomik Sektörler & $\begin{array}{l}\text { Etkenlik } \\
\text { Katsayısı }\end{array}$ \\
\hline 16 & Kok kömürü, petrol ürünleri ve nükleer yakıt im. & 0,479492 \\
\hline 8 & Gıda ürünleri ve içecek imalatı & 0,529764 \\
\hline 14 & Kağıt ve kağıt ürünleri imalatı & 0,557836 \\
\hline 21 & Makine ve teçhizatı hariç; metal eşya sanayii & 0,591678 \\
\hline 24 & B.y.s. elektrikli makine ve cihazların imalatı & 0,682937 \\
\hline 9 & Tütün ürünleri imalatı & 0,70776 \\
\hline 22 & B.y.s. makine ve teçhizat imalatı & 0,723702 \\
\hline 37 & Oteller ve lokantalar & 0,74175 \\
\hline 19 & Metalik olmayan diğer mineral ürünlerin imalatı & 0,757087 \\
\hline 18 & Plastik ve kauçuk ürünleri imalatı & 0,770522 \\
\hline 43 & Mali aracı kuruluşların faaliyetleri & 0,797936 \\
\hline 13 & Ağaç ve mantar ürünleri imalatı (mobilya hariç) & 0,805105 \\
\hline 17 & Kimyasal madde ve ürünlerin imalatı & 0,818117 \\
\hline 27 & Motorlu kara taşıtı , römork ve yarı-römork im. & 0,855597 \\
\hline 1 & Tarım, avcılık hizmet faaliyetleri & 0,857134 \\
\hline 10 & Tekstil ürünleri imalatı & 0,875604 \\
\hline 56 & Eğlence, dinlenme, kültür ve sporla faaliyetleri & 0,879429 \\
\hline 7 & Taşocakçılığı ve diğer madencilik & 0,910683 \\
\hline 35 & Motorlu taşıtlar dışında kalan toptan ticaret ve komisyon. & 0,923247 \\
\hline 42 & Posta ve telekomünikasyon & 0,926767 \\
\hline 46 & Gayrimenkul faaliyetleri & 0,986084 \\
\hline 25 & Radyo, televizyon, haberleşme cihazları im. & 1,020382 \\
\hline 20 & Ana metal sanayii & 1,032822 \\
\hline 28 & Diğer ulaşım araçlarının imalatı & 1,041438 \\
\hline 26 & Tıbbi aletler; hassas ve optik aletler imalatı & 1,046742 \\
\hline 33 & İnşaat & 1,056054 \\
\hline 57 & Diğer hizmet faaliyetleri & 1,073511 \\
\hline 11 & Giyim eşyası imalatı; kürkçülük ve boyanması & 1,077076 \\
\hline 41 & Destekleyici ulaştırma faaliyetleri; seyahat acent. & 1,09227 \\
\hline 40 & Havayolu taşımacılığı & 1,093557 \\
\hline 4 & Maden kömürü, linyit ve turba çıkarımı & 1,133836 \\
\hline 50 & Diğer iş faaliyetleri & 1,148177 \\
\hline 38 & Kara taşımacılığı ve boru hattıyla taşımacılık & 1,149421 \\
\hline 36 & Motorlu taşıtlar dışında kalan perakende ticaret, eşya tam. & 1,152555 \\
\hline 52 & Eğitim hizmetleri & 1,186765 \\
\hline 53 & Sağlık işleri ve sosyal hizmetler & 1,21101 \\
\hline 29 & Mobilya ımalatı; b.y.s. diğer imalat & 1,213237 \\
\hline 47 & Operatörsüz makine, ev eşyalarının kiralanması & 1,223133 \\
\hline 15 & Basım ve yayım; plak, kaset v.b. kayıtlı medya & 1,226802 \\
\hline 32 & Suyun toplanması, arıtılması ve dağıtılması & 1,229021 \\
\hline 30 & Yeniden değerlendirme & 1,234955 \\
\hline 51 & Kamu yönetimi ve savunma, sosyal güvenlik & 1,244601 \\
\hline 48 & Bilgisayar ve ilgili faaliyetler & 1,295578 \\
\hline 45 & Mali aracı kuruluşlara yardımcı faaliyetler & 1,319939 \\
\hline 6 & Metal cevheri madenciliği & 1,324998 \\
\hline 34 & Motorlu taşıtlar satışı, bakımı ve onarımı & 1,383453 \\
\hline 49 & Araştırma ve geliştirme hizmetleri & 1,396712 \\
\hline 31 & Elektrik, gaz, buhar ve sıcak su üret. ve dağıtımı & 1,415494 \\
\hline 3 & Balıkçılık, balık üretme ve yetiştirme hiz. & 1,439204 \\
\hline 44 & Sigorta ve emeklilik fonları ile ilgili faaliyetler & 1,501255 \\
\hline 23 & Büro, muhasebe ve bilgi işlem makineleri im. & 1,506045 \\
\hline 5 & Ham petrol ve doğalgaz çıkarımı (Arama hariç) & 1,522567 \\
\hline 12 & Deri işleme ve deri ürünleri imalatı & 1,540808 \\
\hline 39 & Su yolu taşımacılığı & 1,561079 \\
\hline 54 & Kanalizasyon, çöp ve atıkların toplanması, & 1,566806 \\
\hline 55 & Başka yerde sınıflandırılmamış kuruluşların faal. & 1,731078 \\
\hline 2 & Ormancılık, tomrukçuluk faaliyetleri & 1,835835 \\
\hline
\end{tabular}

(Kaynak: TÜIK 2002 yılı Türkiye ve 2009 yılı Kazakistan Girdi-Çıktı Sonuç tabloları kullanılarak yazarlar tarafından hazırlanmıştır.) 
Tablo 5: Türkiye ve Kazakistan Ekonomilerinin Aramalı Kullanımı Etkenlik Dereceleri

\begin{tabular}{|c|c|c|c|c|}
\hline \multirow{2}{*}{$\begin{array}{l}\text { Sira } \\
\text { No }\end{array}$} & \multirow{2}{*}{ Ekonomik Sektörler (1-7) } & \multicolumn{3}{|c|}{ Aragirdi Kullanımları ve Oranı } \\
\hline & & Türkiye & Kazakistan & $(\mathrm{TR} / \mathrm{KZ})$ \\
\hline 1 & Tarım, avcılık hizmet faaliyetleri & 28.983 .704 & 35.121 .343 & 0,8252 \\
\hline 2 & Ormancılık, tomrukçuluk faaliyetleri & 739.645 & 633.692 & 1,1672 \\
\hline 3 & Balıkçılık, balık üretme ve yetiștirme hiz. & 251.423 & 445.486 & 0,5644 \\
\hline 4 & Maden kömürü, linyit ve turba çıkarımı & 1.586 .977 & 5.312 .995 & 0,2987 \\
\hline 5 & Ham petrol ve doğalgaz çıkarımı (Arama hariç) & 8.421 .979 & 8.263 .472 & 1,0192 \\
\hline 6 & Metal cevheri madenciliği & 659.463 & 6.356 .840 & 0,1037 \\
\hline 7 & Tașocakçılığı ve diğer madencilik & 3.441 .130 & 1.372 .677 & 2,5069 \\
\hline 8 & Gıda ürünleri ve içecek imalatı & 12.660 .595 & 13.579 .665 & 0,9323 \\
\hline 9 & Tütün ürünleri imalatı & 166.717 & 160.182 & 1,0408 \\
\hline 10 & Tekstil ürünleri imalatı & 22.888 .050 & 10.729 .448 & 2,1332 \\
\hline 11 & Giyim eşyası imalatı; kürkçülük ve boyanması & 1.862 .044 & 683.191 & 2,7255 \\
\hline 12 & Deri işleme ve deri ürünleri imalatı & 1.654 .519 & 97.377 & 16,9908 \\
\hline 13 & Ağaç ve mantar ürünleri imalatı (mobilya hariç) & 2.110 .539 & 3.656 .228 & 0,5772 \\
\hline 14 & Kağıt ve kağıt ürünleri imalatı & 6.373 .556 & 4.330 .836 & 1,4717 \\
\hline 15 & Basım ve yayım; plak, kaset v.b. kayıtlı medya & 2.580 .212 & 1.855 .193 & 1,3908 \\
\hline 16 & Kok kömürü, petrol ürünleri ve nükleer yakıt im. & 9.198 .134 & 10.773 .063 & 0,8538 \\
\hline 17 & Kimyasal madde ve ürünlerin imalatı & 20.893 .959 & 23.149 .793 & 0,9026 \\
\hline 18 & Plastik ve kauçuk ürünleri imalatı & 7.562 .078 & 5.559 .796 & 1,3601 \\
\hline 19 & Metalik olmayan diğer mineral ürünlerin imalatı & 9.069 .970 & 6.207 .955 & 1,4610 \\
\hline 20 & Ana metal sanayii & 19.795 .767 & 17.615 .166 & 1,1238 \\
\hline 21 & Makine ve teçhizatı hariç; metal eşya sanayii & 6.044 .525 & 8.063 .211 & 0,7496 \\
\hline 22 & B.y.s. makine ve techizat imalatı & 5.828 .230 & 8.255 .527 & 0,7060 \\
\hline 23 & Büro, muhasebe ve bilgi ișlem makineleri im. & 489.262 & 106.438 & 4,5967 \\
\hline 24 & B.y.s. elektrikli makine ve cihazların imalatı & 4.101 .015 & 3.126 .914 & 1,3115 \\
\hline 25 & Radyo, televizyon, haberleșme cihazları im. & 2.937 .828 & 1.600 .278 & 1,8358 \\
\hline 26 & Tıbbi aletler; hassas ve optik aletler imalatı & 553.066 & 882.590 & 0,6266 \\
\hline 27 & Motorlu kara taşıtı, römork ve yarı-römork im. & 5.034 .052 & 1.983 .907 & 2,5374 \\
\hline 28 & Diğer ulaşım araçlarının imalatı & 1.313 .236 & 4.626 .189 & 0,2839 \\
\hline 29 & Mobilya ımalatı; b.y.s. diğer imalat & 1.210 .823 & 157.644 & 7,6808 \\
\hline 30 & Yeniden değerlendirme & 49.139 & 456.780 & 0,1076 \\
\hline 31 & Elektrik, gaz, buhar ve sıcak su üret. ve dağıtımı & 15.096 .077 & 12.053 .860 & 1,2524 \\
\hline 32 & Suyun toplanması, arıtılması ve dağıtılması & 1.585 .549 & 273.288 & 5,8017 \\
\hline 33 & İnşaat & 2.623 .632 & 15.514 .576 & 0,1691 \\
\hline 34 & Motorlu taşıtlar satışı, bakımı ve onarımı & 8.549 .113 & 3.576 .524 & 2,3903 \\
\hline 35 & Motorlu taşıtlar dışında toptan tic. ve komisyon. & 15.813 .400 & 3.396 .570 & 4,6557 \\
\hline 36 & Motorlu taşıtlar dışında perakende tic., eşya tam. & 10.205 .004 & 279.906 & 36,4587 \\
\hline 37 & Oteller ve lokantalar & 2.187 .047 & 3.926 .486 & 0,5570 \\
\hline 38 & Kara taşımacılığı ve boru hattıyla taşımacılık & 19.510 .350 & 7.509 .892 & 2,5980 \\
\hline 39 & Su yolu taşımacılığı & 4.366 .234 & 382.351 & 11,4194 \\
\hline 40 & Havayolu taşımacılığı & 1.677 .793 & 1.077 .520 & 1,5571 \\
\hline 41 & Destekleyici ulaștırma faaliyetleri; seyahat acent. & 10.672 .118 & 8.895 .991 & 1,1997 \\
\hline 42 & Posta ve telekomünikasyon & 4.725 .675 & 8.600 .315 & 0,5495 \\
\hline 43 & Mali aracı kuruluşların faaliyetleri & 13.938 .519 & 7.671 .402 & 1,8169 \\
\hline 44 & Sigorta ve emeklilik fonları ile ilgili faaliyetler & 886.498 & 570.316 & 1,5544 \\
\hline 45 & Mali aracı kuruluşlara yardımcı faaliyetler & 1.058 .321 & 750.733 & 1,4097 \\
\hline 46 & Gayrimenkul faaliyetleri & 6.247 .778 & 17.467 .560 & 0,3577 \\
\hline 47 & Operatörsüz makine, ev eşyalarının kiralanması & 688.860 & 5.900 .292 & 0,1168 \\
\hline 48 & Bilgisayar ve ilgili faaliyetler & 964.384 & 1.971 .530 & 0,4892 \\
\hline 49 & Araştırma ve geliştirme hizmetleri & 1.379 .598 & 880.737 & 1,5664 \\
\hline 50 & Diğer is faaliyetleri & 14.379 .558 & 16.375 .302 & 0,8781 \\
\hline 51 & Kamu yönetimi ve savunma, sosyal güvenlik & 85.901 & 0,0000 & 0,0000 \\
\hline 52 & Eğitim hizmetleri & 588.438 & 307.592 & 1,9130 \\
\hline 53 & Sağlık işleri ve sosyal hizmetler & 501.043 & 576.580 & 0,8690 \\
\hline 54 & Kanalizasyon, çöp ve atıkların toplanması, & 304.434 & 677.927 & 0,4491 \\
\hline 55 & Başka yerde sınıflandırılmamıș kurulușların faal. & 1.382 .342 & 0,0000 & 0,0000 \\
\hline 56 & Eğlence, dinlenme, kültür ve sporla faaliyetleri & 2.021 .178 & 1.560 .920 & 1,2949 \\
\hline \multirow[t]{2}{*}{57} & Diğer hizmet faaliyetleri & 239.404 & 375.689 & 0,6372 \\
\hline & Toplam & 330.139 .886 & 305.737 .736 & 1,0798 \\
\hline
\end{tabular}

( Kaynak: TÜiK 2002 yılı Türkiye ve 2009 yılı Kazakistan Girdi-Çıktı Sonuç tabloları kullanılarak yazarlar tarafından hazırlanmıştır. ) 